\title{
O DIÁRIO DE BORDO COMO INSTRUMENTO DE AVALIAÇÃO NO MÉTODO DE ENSINO DAS ESTAÇÕES DOS SABERES
}

Semana Online Científica de Educação, 1a edição, de 25/10/2021 a 27/10/2021

ISBN dos Anais: 978-65-81152-18-5

MATOS; ABRAÃO DOS SANTOS ${ }^{1}$, SILVA; Josué Cândido da ${ }^{2}$

\section{RESUMO}

A avaliação como instrumento classificatório e/ou seletivo tem sido usada a mais de 500 anos no ocidente, sendo evidenciada sua prática há cerca de 3000 anos antes da era cristã. Contudo, no ambiente escolar tem funcionado como uma ação que incorpora tensões constituintes das práticas sociais e reveladora de seus vínculos com as ações escolares, sendo que muitos têm-na utilizado como mecanismo de punição e exclusão de alguns estudantes. Nesse contexto, há discussões no âmbito educacional, sobre uma mudança de visão que direcione os professores a considerarem a avaliação, como uma ferramenta direcionada a construção coletiva de uma escola de qualidade para todos. Nessa perspectiva, a presente pesquisa buscou colaborar para a construção de novos caminhos acerca dos processos avaliativos utilizados pelos professores na educação básica, uma vez que propõe uma nova forma de avaliar a aprendizagem com base em modelos existentes no presente, mas com um olhar mais holístico do processo de aprendizagem. A presente pesquisa, faz parte do produto educacional do Método das Estações dos Saberes (ES) e seu desenvolvimento ocorreu por meio da pesquisa-ação, numa abordagem qualitativa de Estudo de Caso, desenvolvida em três etapas: coleta de dados a partir da visita a escola e observação de seus espaços; a prática dos professores, no contexto do Método ES, seguida da aplicação de um questionário semiestruturado e por fim, mediante a análise destes dados, foi proposto um novo instrumento de avaliação que melhor se adequasse ao Método ES, desenvolvido no âmbito do projeto das Escolas de Tempo e Ensino Integral do Estado da Bahia. A validação da pesquisa se deu a partir da comparação entre a avaliação tradicional e o novo método proposto, partindo-se dos dados coletados na instituição onde o mesmo foi proposto e por meio dos indicadores de aprendizagem da educação básica.

PALAVRAS-CHAVE: Estações dos Saberes, Avaliação da aprendizagem, Ensino inovador 